\title{
The effect of curriculum design on the employability competency of Malaysian graduates
}

\author{
Farahana Misni ${ }^{a^{*}}$, Nik Hasnaa Nik Mahmood ${ }^{a}$ and Rossilah Jamil ${ }^{b}$
}

${ }^{a}$ Razak Faculty of Technology and Informatics, UTM Kuala Lumpur, Level 7, Razak Tower, Jalan Sultan Yahya Petra, 54100 Kuala Lumpur, Malaysia

${ }^{b}$ Azman Hashim International Business School, UTM Kuala Lumpur, Level 10, Razak Tower, Jalan Sultan Yahya Petra, 54100 Kuala Lumpur, Malaysia

\section{H R O N I C L E}

\begin{tabular}{l}
\hline Article history: \\
Received: August 82019 \\
Received in revised format: Sep- \\
tember 202019 \\
Accepted: October 3, 2019 \\
Available online: \\
October 3, 2019 \\
\hline Keywords: \\
Curriculum design \\
Employability competency \\
Graduates \\
Higher education institutions
\end{tabular}

\section{A B S T R A C T}

\begin{abstract}
For a country to support the transition of all economic sectors to a knowledge-driven one, attract foreign investment, and drive labor productivity, it is necessary to have access to skilled workforce. However, there is currently an insufficient talent supply and the workforce demand does not match the talent supply because of low graduate employability stemming from the low quality of higher education in Malaysia. To address this issue, this study proposed a conceptual framework to illustrate the perception of graduates towards the impact of curriculum design, the curriculum vision, the operationalization of the curriculum vision, the curriculum delivery, and curriculum evaluation, on employability competency. A sample of 299 employed graduates participated in this research. Smart Partial Least-Squares (SmartPLS) version 3 software was used to evaluate the hypotheses of the survey. The findings of this study reveal that curriculum design positively and significantly influenced employability competency. Hence, this study contributes important insights into the implementation of effective curriculum design, striking a balance between practical and theoretical bases, in private and public Higher Education Institutions (HEIs).
\end{abstract}

C 2020 by the authors; licensee Growing Science, Canada

\section{Introduction}

Previous works such as Shagrir (2015) and Turner (2014) have highlighted a long-standing argument regarding the function of Higher Education Institutions (HEIs) in bolstering the employability of graduates. For instance, the importance of universities and their educational systems in developing graduate employability and improving fragile economies have been emphasized in Mbah's (2014) study. Nevertheless, other studies have highlighted some issues that remain such as the university's suitability in preparing students to face workplaces in ever-changing industries (Aziz et al., 2016). The challenging conditions of today have intensified stakeholder pressure on universities, especially pressure from the industry, to ensure that students are equipped with more than just academic skills. Griffin and Annulis (2013) discovered that the most common employer complaints revolved around new graduates that lacked decision-making, problem-solving, teamwork, and self-learning skills, instead, emerging from university with heads full of theories without the knowledge to apply them. There have been numerous attempts such as Qenani et al. (2014) and Aguila et al. (2016), which investigated graduate competencies against the relevant skills required by the employer. Nevertheless, not much empirical research has been done to assess the role of Higher Education Institutions (HEIs) in developing these competencies. This gap in the research area has also been highlighted in the past studies, which found that further research is still needed to assess the effectiveness of teaching and learning strategies in developing highly sought-after employability skills among graduates (Alias et al., 2013). Therefore, to keep up-to-date with the employers' demand for graduate skills in the market, HEIs must restructure their curriculum. In line with this objective, this work aims to assess the impact of curriculum design on Malaysian graduate employability competencies. Malaysia was chosen as a case study because this is a developing country. Anderson and Rogan (2011) highlighted the components that are important to consider when designing a curriculum. Hence, how employability competency can be enhanced through curriculum design can be investigated (Abdul Hamid et al., 2014; Alias et al., 2013). In theory, this article contributes fresh perspectives for integrating new variables under curriculum design (Anderson \& Rogan, 2011) such as vision, operationalization

* Corresponding author.

E-mail address: farahana.misni@yahoo.com (F. Misni) 
of vision, delivery, and evaluation, linked to the human capital theory (Schultz, 1963) to understand employability competency. This study investigates the effect of selected curriculum design variables, namely curriculum vision, operationalization of curriculum vision, curriculum delivery, and curriculum evaluation, on employability competency. The next section further explains these variables and defines employability competency. Then, the literature review on the effect of the curriculum components on employability is presented. Next, the research methodology is explained in detail, following which the findings of the research are presented and discussed. The practical implications of this study and the directions for future work conclude this paper.

\subsection{Research Questions}

$\mathrm{R}_{1}$ : Does curriculum design positively affect employability competency?

$\mathrm{R}_{2}$ : Does curriculum design have any effect on employability competency?

\subsection{Hypotheses of the Study}

$\mathrm{H}_{1}$ : Curriculum design positively affects employability competency.

$\mathrm{H}_{1 \mathrm{a}}$ : Curriculum Vision positively affects employability competency.

$\mathrm{H}_{1 \mathrm{~b}}$ : Operationalization of Curriculum Vision positively affects employability competency.

\section{Literature Review}

\subsection{Employability Competency}

Numerous studies have extensively investigated the concept of employability, giving rise to equally extensive definitions of the concept. Employability, according to Yorke (2006), traces its roots back to education, focusing on related achievements and the graduates' ability to perform job functions; and contrary to popular belief is not all about securing a job. Therefore, according to education institutes, employable graduates are those that have the skills and competencies that guarantee their employment. There are two broad categories under employability (Harvey, 2001); i) the student's ability to secure a job after graduating; and ii) empowering the student to become a life-long learner by equipping them with the necessary knowledge, skill, attitude, and ability (Harvey, 2001; Hillage \& Pollard, 1998). The most important raw material for new graduates, as perceived by companies, is the possession of entry-level employability skills. According to industry analysts, these skills will increase the chances of success in the workplace. Rasul et al. (2013) further emphasized the need for institutions to instill not only technical skills, but also employability skills in students. According to Yusof and Jamaluddin (2015), the majority of manpower strategies and the main target of most labor market policies in many countries are now focusing on graduate employability. Employability skills are not, however, the responsibility of education institutions alone; industrial organizations and higher education departments are also equally responsible ( $\mathrm{Su} \&$ Zhang, 2015). Graduate employability has become the main concern of policymakers, learning institutions, employers, and graduates. Since the proportion of skilled workers remains relatively low, upgrading workforce skills is a quite overwhelming challenge facing the government. A Tracer Study on Malaysian graduates in 2016 showed that unemployment among new graduates was more than seven times the national rate, which was 3.1\% (Shanmugam, 2017). Meanwhile, MOE (2017) indicated that the rate had been consistent since 2010 (24.6\%). It was slightly higher in 2011 and 2012 (25.6\% and 25\%, respectively), dropping in 2015 to $24.9 \%$ and most recently declining yet again to $22.7 \%$ in 2016 (MOE, 2017). Even with the employability issues being targeted by university and ministerial policies, and notwithstanding the extensive debates and discussion on this issue, the trend of unemployment is still prevalent, where the cause can be traced back to the incompatibility between the graduate competencies expected by the employers and the HEIs (Singh et al., 2014). All countries are now facing the same primary problem; how can education and training assist in developing global skills among students that could be transferred and translated from any country to any host country? To be employable, graduates should have a good mix of academic and practical skills. Mansour and Dean (2016) agreed with the above, stressing that HEIs should implement approaches that would ensure students are adequately prepared to successfully take up a wide variety of jobs. Universities must realize that employability skills go way beyond securing or searching for a job; graduates should also have skillsets, individual techniques, and attributes that would ensure they succeed in their jobs as well. Most importantly, to supply graduates with the right skillsets demanded by the job market, universities should understand the demanded skills that employers require to prevent a mismatch between supply and demand.

\subsection{Theorizing Employability Competency}

The components or variables of curriculum design were adapted from the work of Anderson and Rogan (2011). These components are curriculum vision, operationalization of curriculum vision, curriculum delivery, and curriculum evaluation. The relationship between employability and the curriculum design variables are explained using the human capital theory posited by Schultz (1963). 


\subsubsection{The Theory of Human Capital}

Schultz (1963) introduced the human capital theory, which delineates the important role of education in developing people and the economy. The quality of education and its facilities could be greatly enhanced with the help of investments or financial contributions. On the other hand, education helps develop talent and potential. In short, one's ability can be disciplined, trained, and revealed via education. Therefore, students could be groomed into productive workers through education; and can, therefore, be seen as a form of human investment. According to this line of thinking, it is not a waste to invest in education. Undoubtedly, when the worker's productivity is increased, the nation's economy also increases; education develops a quality workforce that in turn drives up the country's production, especially impacting the nation's economic gains. The human capital theory resonates with this study; once the Malaysian government at all levels is committed to providing quality education to develop human capital, the output of Malaysian universities will improve.

\subsection{Predictors of Employability Competency}

\subsubsection{Curriculum Design and Employability Competency}

The components of curriculum design were obtained from the model of Anderson and Rogan (201), namely curriculum vision, operationalization of curriculum vision, curriculum delivery, and curriculum evaluation. In particular, several studies have examined the university curriculum and provided evidence that supports its impact on employability competency (Jansen \& Suhre, 2015; Harry et al., 2018; Ahmed et al., 2019; Aguila et al., 2016). Kennedy and Juliet (2013) used the human capital theory to highlight education's role in upgrading the skills of an individual, stating that besides special and technical skills, graduates must also be able to efficiently and effectively function in the working world by equipping themselves with the right employability skills. Johan (2015) found that one of the important performance indicators that show HEIs are providing quality education is the employability of their graduates. In line with this, a critical, indispensable teaching and learning component that could enhance the attributes that make an individual more employable, is curriculum design (Nixon \& Williams, 2014; Nguyen, 2014). Anderson and Rogan (2011) indicated that curriculum vision sets the tone for the learning outcomes of particular curriculum design in HEIs, especially when it comes to the competencies and skills required to be successful in the job landscape. As part of curriculum vision, graduates must be competent at the workplace and fulfil employer expectations. The factors influencing market demands must also be emphasized. Meanwhile, the components under the operationalization of the curriculum vision, according to Johnson-Mardones (2014), include the structures of human resource and teaching material required to deliver the course. Johan (2015) found in his study that students had better perceptions of lecturers that have had prior experience in the industry. Four key elements have been identified under curriculum delivery, namely fostering a deep learning approach, conceptual understanding development, and inculcating abilities to problem-solve among students (Anderson \& Rogan, 2011). Davies (2013) stated that teaching that focuses on developing creative and critical skills will engender the integration of conceptual knowledge on topics and problems associated with the interest and skills development focused on. To further improve graduate development, it seems crucial to regularly assess the experiences of students and their learning observations as part of curriculum evaluation (Jansen \& Suhre, 2015). In this way, the information obtained under the course evaluation could be used as feedback to improve the rest of the curriculum components, if needed (Anderson \& Rogan, 2011). The research model proposed in this paper is illustrated in Fig. 1.

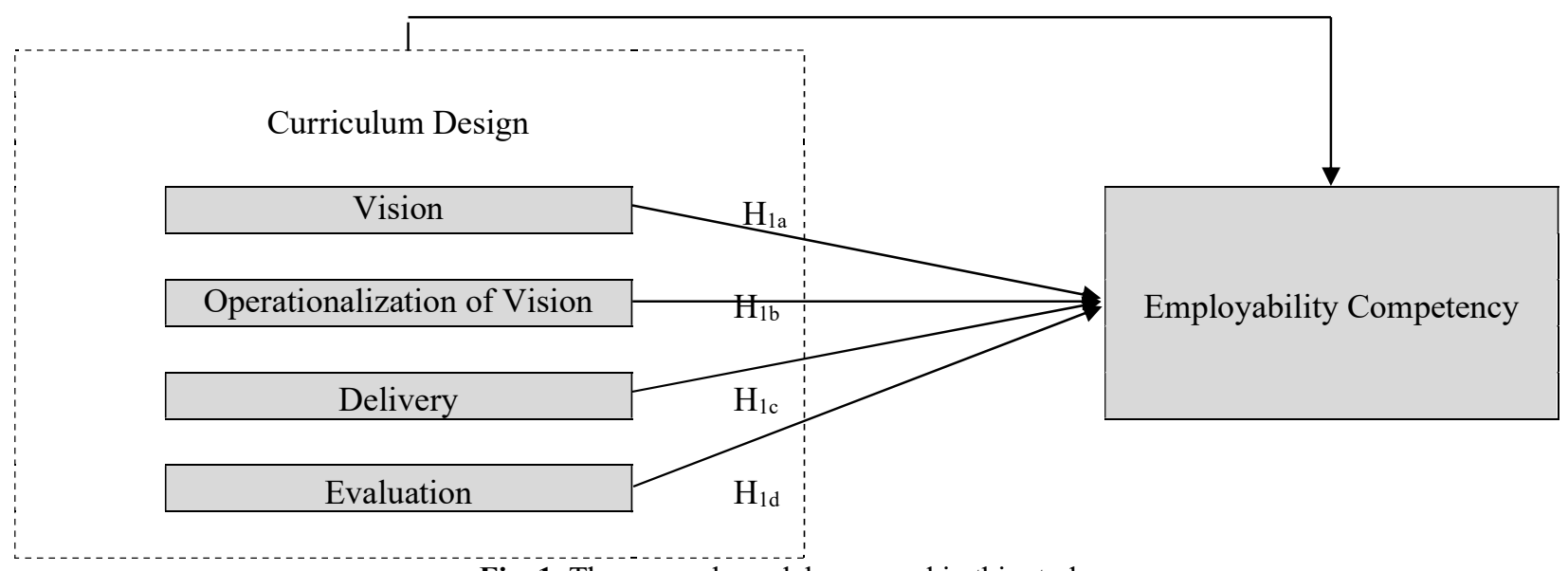

Fig. 1. The research model proposed in this study

\section{Research Methodology}

Since this study focused on employability competency at the individual level, the focus was placed on sampling Higher Education Institutions (HEIs) in Malaysia through a target population comprising of graduates who had pursued their Bachelor's Degree in both public and private universities in 2013-2015 (i.e. 3 years), and are employed. This study only focused on local universities (public and private). However, it is impossible for the researcher to examine all members of the related population. Hence, in such situations, non-probability sampling is utilized, as the probability of including each element of the population 
in a sample is unknown (Cooper \& Schindler, 2014). Therefore, the researcher decided to distribute the questionnaire using several methods to reach the target respondents, namely via enumerators working in a few of the SL1M companies in the area of Kuala Lumpur (e.g. MBSB, PNB, TNB, and Sime Darby); sending an e-mail to the list of graduates obtained from a few universities; and meeting part-time postgraduate students at UTM in person. Thus, the most-cited rules of thumb for statistically evaluating models using SEM were referred to determine the sample size for this study. As a general rule, SEM research studies require a minimum sample of 200. This study collected data from 299 respondents, which are well beyond the minimum sample size required. Then, Structural Equation Modeling (SEM) was used to analyze the collected data. Following that, SmartPLS 3.0 M3 (Ringle et al., 2015) path modeling software package was used to design and construct a reflective model for further two-stage analysis.

\section{Analysis of data and the results}

\subsection{Respondent Profile}

Out of 299 respondents, $54.8 \%$ are females and $45.2 \%$ are males. The majority $(45.5 \%)$ of the respondents who participated in the survey were 22-25 years old and 26-29 years old. Meanwhile, only a few respondents (9\%) were 30 years old and above. A total of 220 of 299 respondents $(73.6 \%)$ were from public universities. About 133 of the respondents graduated in 2013 followed by 123 (41.1\%) 2015 graduates. Only 43 respondents graduated in 2014. This distribution of respondents is based on graduates with a Bachelor's degree from a public or private university that was employed within 3 years of graduation. In terms of the discipline of study, the majority of the respondents studied Social Sciences and the Arts (46.8\%), followed by Technical \& Engineering (26.4\%), Science (16.1\%), Information \& Communications Technology (10\%), and Education $(7 \%)$. The majority $(55.5 \%)$ of respondents had graduated with a $2^{\text {nd }}$ class lower, $3.00-3.49$ CGPA results while a very few $(6 \%)$ had graduated with $1^{\text {st }}$ class honors (4.00-3.75 CGPA). Most (58.5\%) of the respondents studied for 3 years to get their degree. For industrial training, the majority $(89 \%)$ of the respondents had attended industrial training as part of the course syllabus, normally taken in the last semester. The duration of industrial training was mostly within 4-6 months (70.2\%). Most of the respondents ( 211 respondents or $70.6 \%$ ) had working experience of 1-2 years, while the least percentage of respondents (5.7\% or 17 respondents) had more than 5 years' working experience. Regarding company ownership, the majority (81.6\%) of the respondents worked at local companies, and $18.4 \%$ of the total respondents worked at foreign companies. Based on this distribution, about 32.4\% (97 respondents) worked in the Banking/Finance/Insurance sector and only $1(0.3 \%)$ person worked in the Agriculture sector. The majority (44.8\%) of the respondents worked at big companies with employees numbering 1000 and more. Only $13.4 \%$ of the respondents worked at companies with 500-999 employees.

\subsection{Internal Consistency, $(\alpha, p c)$}

The internal consistency of the research instruments was measured using Cronbach's alpha and composite reliability, where Table 1 lists the respective values of each research construct. The composite reliability (CR) can vary between 0 and 1 with values larger than 0.70 considered acceptable (Hair et al., 2016).

Table 1

Internal consistency of the constructs (Cronbach's alpha and composite reliability)

\begin{tabular}{|c|c|c|c|c|c|}
\hline Construct & Cronbach's Alpha & Composite Reliability & Construct & $\begin{array}{c}\text { Cronbach's } \\
\text { Alpha }\end{array}$ & $\begin{array}{l}\text { Composite } \\
\text { Reliability }\end{array}$ \\
\hline Curriculum Vision & 0.79 & 0.863 & Communication Skills & 0.878 & 0.91 \\
\hline Operationalization of Vision & 0.797 & 0.868 & Informational Management & 0.877 & 0.915 \\
\hline Curriculum Delivery & 0.77 & 0.866 & Leadership Skills & 0.842 & 0.893 \\
\hline Curriculum Evaluation & 0.855 & 0.932 & Entrepreneurship Skills & 0.889 & 0.923 \\
\hline Management Skills & 0.76 & 0.861 & Personal Qualities & 0.834 & 0.9 \\
\hline Teamwork Skills & 0.887 & 0.928 & System and Technology & 0.863 & 0.907 \\
\hline Thinking Skills & 0.829 & 0.886 & & & \\
\hline
\end{tabular}

\subsection{Assessment of Collinearity Issue}

If two or more independent variables in a research model are highly correlated, the problem of multicollinearity could occur. The variance of inflation factors (VIFs) was obtained to determine any issues of multicollinearity in this study. An analysis might become biased if there is a collinearity issue. A potential collinearity issue is indicated by a VIF value $\geq 5$ (Hair et al., 2011 or $\geq 3.3$ (Diamantopoulos \& Sigouw, 2006). Table 2 lists the independent variable VIF values of the present study.

Table 2

VIF value of all constructs

\begin{tabular}{|c|c|c|c|c|}
\hline Variable & Curriculum Vision & Operationalization of Vision & Curriculum Delivery & Curriculum Evaluation \\
\hline Employability Competency & 1.02 & 1.09 & 1.10 & 1.11 \\
\hline
\end{tabular}

\subsection{Significance and relevance of the variable relationships}

As per the method outlined in Hair et al. (2016), the standard path coefficients, standard errors and t-value were determined using PLS3 software to test the significance of each hypothesis relationship. In this method, 500 resamples were bootstrapped. As shown in Table 3, there was a positive $(\beta=0.337, \mathrm{p}=0.000)$ and significant $(\mathrm{p}<0.01)$ relationship between employability 
competency and the curriculum design-construct based on the latter's direct path coefficients. The results prove that $\mathrm{H}_{1}, \mathrm{H}_{1 \mathrm{a}}$, $\mathrm{H}_{1 \mathrm{~b}}$, and $\mathrm{H}_{1 \mathrm{c}}$ are supported, where positive relationships were obtained between curriculum vision and employability competency $(\beta=0.134, p=0.000)$; curriculum delivery and employability competency $(\beta=0.202, p=0.008)$; and operationalization of curriculum vision and employability competency $(\beta=0.177, \mathrm{p}=0.008)$. However, H1d, which posits that curriculum evaluation directly affects employability competency, was found insignificant $(\beta=0.177, \mathrm{p}=0.537)$.

Table 3

Variable relationships_-significance and relevance

\begin{tabular}{|c|c|c|c|c|c|}
\hline Relationship & Beta & Std. Err. & t-value & Sig. & Decision \\
\hline Curriculum Design $\rightarrow$ Employability Competency (H1) & 0.337 & 0.047 & 7.185 & 0.000 & Sig./Supported \\
\hline Curriculum Vision $\rightarrow$ Employability Competency (H1a) & 0.134 & 0.051 & 2.653 & 0.008 & Sig./Supported \\
\hline Operationalization of Curriculum Vision $\rightarrow$ Employability Competency $(\mathrm{H} 1 \mathrm{~b})$ & 0.177 & 0.056 & 3.149 & 0.002 & Sig./Supported \\
\hline Curriculum Delivery $\rightarrow$ Employability Competency (H1c) & 0.202 & 0.045 & 4.495 & 0.000 & Sig./Supported \\
\hline Curriculum Evaluation $\rightarrow$ Employability Competency (H1d) & 0.031 & 0.050 & 0.618 & 0.537 & Not Sig./Not Supported \\
\hline
\end{tabular}

; t-value $>1.96 * *(\mathrm{p}<0.05) ; \mathrm{t}$-value $>2.58 * * *(\mathrm{p}<0.001)$

\section{$4.5 R^{2}$ (Coefficient of Determination)}

The coefficient of determination, $\mathrm{R}^{2}$, according to Hair et al. (2016), shows the extent to which an exogenous construct explains the variance in an endogenous construct. It also shows how much exogenous latent variables share the effect of the endogenous latent variable. It has a value of $0-1$, where the higher the value the higher its predictive accuracy. The coefficient of determination $\left(\mathrm{R}^{2}\right)$ for employability competency was 0.241 . This result indicates that curriculum design can explain 24 percent (0.241) of the variance in employability competency, meaning that other factors that this study did not cover could explain the other $76 \%$ variance. Cohen (1988) indicated that a substantial model should have an $\mathrm{R}^{2}$ value of 0.67 , followed by a moderate model $\left(\mathrm{R}^{2}=0.33\right)$ and a weak model $\left(\mathrm{R}^{2}=0.19\right)$. The coefficient of determination in this study $(0.241)$ was way below the value of 0.26 suggested by Cohen (1988).

Table 4

$\mathrm{R}^{2}$ value-a summary

$\begin{array}{cc}\text { Endogenous Latent Variable } & \mathrm{R}^{2} \text { Value } \\ \text { Employability Competency } & 0.241\end{array}$

\section{Summary and conclusion}

This study aimed to assess the impact of curriculum design on employability competency. Moreover, this study contributed important insights and empirical findings to extend the works in the literature on employability competency. The study found that curriculum design was directly correlated $(\beta=0.337, \mathrm{p}=0.000)$ with employability competency. Curriculum vision $\left(\mathrm{H}_{1 \mathrm{a}}\right)$, curriculum vision operationalization $\left(\mathrm{H}_{1 \mathrm{~b}}\right)$, and curriculum delivery $\left(\mathrm{H}_{1 \mathrm{c}}\right)$ were all found to positively correlate with employability competency $(\beta=0.134, p=0.008 ; \beta=0.177, p=0.002 ; \beta=0.202, p=0.000$, respectively). However, curriculum evaluation had no significant effect $(\beta=0.177, \mathrm{p}=0.537)$ on employability competency; so $\mathrm{H}_{1 \mathrm{~d}}$ was not supported. To explain the result, curriculum evaluation is a monitoring and assessment tool that relies on other factors outside of the curriculum design; these lead towards the redefining and initiating of the curriculum development cycle. One of the factors involved includes observing the student learning experiences, which are a contributing factor affecting employability competency. It is important to invest in education, as it is through education that people develop and improve their wellbeing. Hence, the education sector should underline employability as a crucial education objective of the university degree, by better understanding the skills required of its graduates. Universities need to incorporate a more hands-on approach, instigate analytical discussions, and apply interactive learning techniques as part of their curriculum to ensure that students are equipped with the skills demanded by employers. Generally, in the context of a developing country especially, graduate employability is strongly dependent on student-related activities and the overall quality of the university. One key solution to overcome current issues of employability is to ensure a demand-driven curriculum education that is also responsive to real needs. The present study empirically proved that the design of the curriculum constructs positively impacted employability competency. The findings agree with the findings of current studies that also emphasized the strong impact of the university curriculum on employability (Iyer \& Dave, 2015; Pheko \& Molefhe, 2016). Nevertheless, there are some limitations on this study. First, it was difficult to trace graduates that had been employed within 3 years after graduating, so the sample in this study was very limited. Second, this study could not provide significant explanations of other variables' predictive influence on employability competency, as only two predictor constructs of curriculum design variables were analyzed. Therefore, this study recommends future work to explore other constructs to extend the work of this study.

\section{References}

Abdul Hamid, M. S., Islam, R., \& Abd Manaf, N. H. (2014). Employability Skills Development Approaches : An Application of the Analytic Network Process. Asian Academy of Management Journal, 19(1), 93-111.

Aguila, G. M., De Castro, E. L., Dotong, C. I., \& Laguador, J. M. (2016). Employability of computer engineering graduates from 2013 to 2015 in one private higher education institution in the Philippines. Asia Pacific Journal of Education, Arts and Sciences, 3(33), 48-54.

Ahmed, Y., Taha, M. H., Alneel, S., \& Gaffar, A. M. (2018). Evaluation of the learning environment and the perceived weakness of the curriculum: student perspective. International Journal of Research in Medical Sciences, 7(1), 165. 
Alias, R., Mohd Hamzah, M. I., \& Yahya, N. (2013). Generic skill requirements: Between employer's aspiration and the need of professional employees. Jurnal Pengurusan, 37, 105-114.

Anderson, T. R., \& Rogan, J. M. (2011). Bridging the educational research-teaching practice gap: Curriculum development, Part 1: Components of the curriculum and influences on the process of curriculum design. Biochemistry and Molecular Biology Education, 39(1), $68-76$.

Aziz, M. I., Afthanorhan, A., \& Awang, Z. (2016). Talent development model for a career in Islamic banking institutions: A SEM approach. Cogent Business \& Management, 3, 1-11.

Cohen, J. (1988). Statistical Power Analysis for the Behavioral Sciences. 2nd ed. Erlbaum. New Jersey.

Cooper, D., \& Schindler, P. (2014). Business research methods. 12th ed. New York: McGraw Hill.

Davies, M. (2013). Critical thinking and the disciplines reconsidered. Higher Education Research \& Development, 32(4), $529-544$.

Diamantopoulos, A., \& Siguaw, J. (2006). Formative Versus Reflective Indicators in Organizational Measure Development: A Comparison and Empirical Illustration. British Journal of Management, 17(4), 263-282.

Griffin, M., \& Annulis, H. (2013). Employability skills in practice: The case of manufacturing education in Mississippi. International Journal of Training and Development, 17(3), 221-232.

Hair, J.F., Hult, G.T.M., Ringle, C.M. \& Sarstedt, M. (2016). A Primer on Partial Least Squares Structural Equation Modelling (PLSSEM). 2nd ed. Sage, Thousand Oaks, CA.

Hair, J., Ringle, C. M., \& Sarstedt, M. (2011). PLS-SEM. Indeed a Silver Bullet. Journal of Marketing Theory \& Practice, 19(2), $139-151$.

Harry, T., Chinyamurindi, W. T., \& Mjoli, T. (2018). Perceptions of factors that affect employability amongst a sample of final-year students at a rural South African university. SA Journal of Industrial Psychology, 44, 1-10.

Harvey, L. (2001). Defining and Measuring Employability. Quality in Higher Education, 7(2), 97-109.

Hillage, J., \& E. Pollard. (1998). Employability: Developing a Framework for Policy Analysis. London: DfEE.

Iyer, V. M., \& Dave, K. (2015). Industry's role in employability. Industrial and Commercial Training, 47(3), 151-158.

Jansen, E. P. W. A., \& Suhre, C. J. M. (2015). Factors influencing students' perceptions of graduate attribute acquisition in a multidisciplinary honours track in a Dutch university. Higher Education Research \& Development, 34(6), 1138-1152.

Johan, K. (2015). Perception of Students Towards Lecturers Teaching Engineering Courses With Industry Experience : A Case Study In Malaysia Technical University. Procedia - Social and Behavioral Sciences, 195, 925-931.

Johnson-Mardones, D. F. (2014). Toward a Multidimensional Concept of Curriculum: Understating Curriculum as Phenomenon, Field and Design. European Journal of Curriculum Studies, 1(2), 172-177.

Kennedy, E., \& Juliet, O. D. (2013). Survey on Employability Skills Among Post Graduate Students of Business Education in Edo State. European Journal of Educational Studies, 5(2), 197-207.

Mansour, B. El, \& Dean, J. C. (2016). Employability Skills as Perceived by Employers and University Faculty in the Fields of Human Resource Development ( HRD ) for Entry Level Graduate Jobs. Journal of Human Resource and Sustainability Studies, 4(3), 39-49.

Mbah, M. F. (2014). The dilemma of graduate unemployment within the context of poverty, scarcity and fragile economy: are there lessons for the university? International Journal of Economics and Finance, 6(12), 27-36.

MOE. (2017). Sistem Laporan Kajian Pengesanan Graduan. Available at: http://graduan.mohe.gov.my

Shanmugam, M. (2017). Unemployment among graduates needs to be sorted out fast. Available at: https://www.thestar.com.my/business/business-news/2017/03/25/.

Nixon, S., \& Williams, L. (2014). Increasing student engagement through curriculum redesign: deconstructing the 'Apprentice'style of delivery. Innovations in Education and Teaching International, 51(1), 26-33.

Nguyen, H. O. (2014). Grounded in Practice: Designing \& Implementing Relevant and Student-Centered Curriculum. Advances in Educational Administration, 21, 161-181.

Pheko, M. M., \& Molefhe, K. (2016). Addressing employability challenges: a framework for improving the employability of graduates in Botswana. International Journal of Adolescence and Youth, 1-15.

Qenani, E., MacDougall, N., \& Sexton, C. (2014). An empirical study of self-perceived employability: Improving the prospects for student employment success in an uncertain environment. Active Learning in Higher Education, 15(3), 199-213.

Rasul, M. S., Abd. Rauf, R. A., \& Mansor, A. N. (2013). Employability skills indicator as perceived by manufacturing employers. Asian Social Science, 9(8), 42-46.

Ringle, C. M., Wende, S., \& Becker, J.-M. (2015). SmartPLS 3. Bönningstedt: SmartPLS

Schultz, T. W. (1963). The Economic Value of Education. New York: John Wiley.

Shagrir, L. (2015). Working with students in higher education - professional conceptions of teacher educators. Teaching in Higher Education, 20(8), 783-794.

Singh, P., Thambusamy, R. X., \& Ramly, M. A. (2014). Fit or Unfit? Perspectives of Employers and University Instructors of Graduates' Generic Skills. Procedia - Social and Behavioral Sciences, 123, 315-324.

Su, W., \& Zhang, M. (2015). An integrative model for measuring graduates' employability skills-A study in China. Cogent Business \& Management, 2(1), 1-11.

Turner, N. K. (2014). Development of self-belief for employability in higher education: ability, efficacy and control in context. Teaching in Higher Education, 19(6), 592- 602.

Yorke, M. (2006). Employability in higher education: what it is - and what it is not. The Higher Education Academy: Learning and Employability Series No. 1. Available at: http://www.heacademy.ac.uk/resources/publications/learningandemployability

Yusof, N., \& Jamaluddin, Z. (2015). Graduate employability and preparedness: A case study of University of Malaysia Perlis (UNIMAP), Malaysia. Malaysian Journal of Society and Space, 11(11), 129-143.

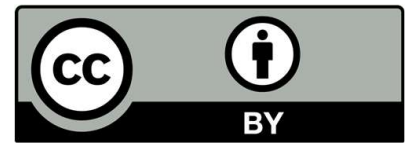

(C) 2020 by the authors; licensee Growing Science, Canada. This is an open access article distributed under the terms and conditions of the Creative Commons Attribution (CC-BY) license (http://creativecommons.org/licenses/by/4.0/). 